Miliša Todorović ${ }^{1}$

SCIENTIFIC REVIEW ARTICLE

Logos Centre College, Mostar, Bosnia and Herzegovina DOI: 10.5937/ekonomika2004085T

Snežana Živković

Faculty of Occupational Safety, Niš, Serbia

Received: April, 08. 2020.

Accepted: Jun, 18. 2020.

\title{
ECONOMIC IMPLICATIONS OF THE ROLE OF INSURANCE IN CREATING A SAFE WORK ENVIRONMENT ${ }^{3}$
}

\begin{abstract}
Purpose - The purpose of this paper is to point out the connection between insurance and occupational safety and health, thus proving the multidisciplinary nature of these scientific disciplines.

Research design/method/approach - Descriptive methods were used to process the data while studying available domestic and foreign literature. In the paper, we will justify the starting hypothesis that linking these two scientific disciplines creates the preconditions for realizing economic benefits both from the level of workers and from the level of the employer and society as a whole. In the first part of the paper the basic concepts of risk in insurance and the economic basis of insurance are presented, while in the second part the basic characteristics of occupational safety are considered.

Practical implication - The final part of the paper outlines the basic economic implications that arise from linking insurance and occupational safety and health, which is a practical implication of the paper itself, since linking the aforementioned disciplines is directly related to employers'legal obligations to insure workers from work injury.

Originality/Value - Analyzing the domestic and international literature, we find that few authors are concerned with the integration of these two disciplines, which represents the original value of the paper.
\end{abstract}

Key words: insurance, occupational safety, risk, economic consequences

JEL classification: I14, I30, J28

\section{ЕКОНОМСКЕ ИМПЛИКАЦИЈЕ УЛОГЕ ОСИГУРАЊА У СТВАРАҢУ БЕЗБЕДНОГ ОКРУЖЕЊА ЗА РАД}

\footnotetext{
Апстракт

Сврха-Сврха овог радајесте да се укаже на повезаност осигурања изаштите на раду чиме се доказује мултидисииплинарност ових научних дисииплина.

${ }^{1}$ milisa.todorovic@logos-centar.com, ORCID ID 0000-0001-6239-4285

${ }^{2}$ snezana.zivkovic@znrfak.ni.ac.rs, ORCID ID 0000-0002-7931-9334

${ }^{3}$ The published paper is the result of research funded by the Ministry of Education, Science and Technological Development of the Republic of Serbia.
} 
Дизајн/Методи/Приступ - За израду рада коришћена је дескриптивна метода уз прочавање доступне домаће и међународне литературе. У раду ћемо доказати полазну хипотезу да повезивање ове две научне дисииплине ствара предуслове за остваривање економских бенефита како са нивоа радника тако и са нивоа послодавца и друштва у целини. У првом делу рада ћемо приказати основне појмове о ризику у осигурању и економској основи осигурања док ћемо у другом делу да се бавимо основним карактеристикама заштите на раду.

Практичне импликачије - $У$ завршном делу рада ћемо приказати везу између осигурања и заштите на раду што представља практичну импликацију самог рада обзиром да довођење у везу поменутих дисичилина јесте у директној вези са законским обавезама послодаваща да осигурају раднике од повреда на раду.

Оригиналност/Вредност - Анализирајући домаћу и међународну литературе утврдили смо да се мало аутора бави повезивањем ове две дисииплине ито представља оригиналну вредност рада.

Кључне речи: осигурање, заштита на раду, ризик, економске последиче.

\section{Introduction}

Massive economic upheaval as a consequence of the global financial crisis and great recession from 2008 to 2010 exposed the vulnerability of economies, both at national and at global level. Nowadays we are faced with the outbreak of COVID 19 virus whose consequences for the world economy cannot be clearly foreseen yet. From the usual GDP growth rate of $2 \%-6 \%$, we are to witness a situation where the most developed countries will face negative growth. We are compelled to carefully consider all factors that could help us deal with the new challenges that lie ahead of us. The world COVID 19 pandemic could have hardly been foreseen so it was impossible to prepare for that risk. However, a large number of other risks that occur in business activities of legal entities can be identified and appropriate and timely measures adopted to deal with them. Therefore, insurance is brought into play and, in simple terms, it can be seen as a professional risk bearer. By insurance policy between the insurer and the insured, known as the policyholder, the insurer agrees to compensate for the losses that may or may not occur (Novaković et al., 2018). Employers are aware that certain risks could endanger their businesses. Insurance companies identify those risks and, according to strict rules defined by the government, they define the cost of risk transfer (Novaković et al., 2017). All potential risks that legal entities might be faced with cannot be listed. What we know as a fact is that even countries themselves offer a framework of risks that can be insured. It is our belief that the creation of safe work environment - an environment where injuries at work are minimized- increases the business competence of any employer. In most countries, legal acts define that the employers are required to insure their employees against workplace injury. There are different legal solutions, some of which will be presented in the paper together with their advantages and disadvantages. The cost of workplace injuries is huge. Numerous studies show that the costs of workplace injuries 
amount to 4\% of GDP in every national economy (Todorović \& Živković, 2010). The economic implications of unsafe work environment still have not been given appropriate attention, neither in theory nor in practice.

Further effort is required in the process of creating appropriate methods and models which will show an unambiguous relation between the employer's obligation to insure the workers against injuries at work and the overall economic consequences that employers are faced with.

\section{Methods}

Data processing was performed by means of descriptive methods along with the analysis of available domestic and foreign literature.

\section{The concept of risk in insurance}

The need to face risks and manage them by appropriate actions has existed for a long time. Even in the distant past, people wanted to prevent risks that occurred due to people's actions or natural disasters. About 5,000 years ago Chinese merchants used to split their goods and transport them in several boats when crossing the Yangtze River. If a boat and the goods sank, all of them as a group compensated for the loss (Avdalović, Ćosić \& Avdalović, 2010). With the development of civilization, the field of insurance has developed, too, with different forms of insurance controlling the relations between the insured and the insurer. The basis of all relations is risk. Risk takes on many forms. One of the main reasons why insurance does not have a more significant role in risk management is the absence of legislation. The absence of clear regulations with clearly stated rights and obligations lead to various manipulations in the past. The insured were often unable to claim compensation although they had paid the insurance premium. This created distrust among policyholders and the insurance has not achieved its full growth yet (Ilić Petković et al., 2019).

The presence of a certain risk implies the need for managing that risk in an effective way. Can employers take measures to reduce risk? Yes, they certainly can. However, there are situations where an employer cannot completely affect the probability of occurrence of a certain risk (Ilić Petković, 2016). Risk in insurance depends on the danger of hazard realization, exposure and sensitivity of the insured property or people to harmful events, and on the insured value (Njegomir \& Ćosić, 2012). Risk is part of life and people have always dealt with risks caused by changes in their surroundings, unforeseen circumstances or fraud (Vujović, 2009). There are numerous risk definitions. One of these defines risk as a situation with the possibility of negative deviation from the expected favourable outcome (Andrijanić \& Klasić, 2002; Mrkšić \& Ćosić, 2015). Thus, risk is the probability of harmful consequences or losses resulting from a given hazard over a specified time period (Ćosić, Popović, Novaković et al., 2019).

Risk is a complex phenomenon consisting of several independent elements which determine its basic characteristics. The basic elements of risk are: uncertainty over the occurrence of an event, hazard, probability of realization and possible damage resulting 
from the realization of hazard. There is a tendency, both in theory and practice, to equate uncertainty with risk although uncertainty is only one part of risk. Risk means that a certain desired situation cannot be foreseen, i.e., that its realization is uncertain.

Risk can be measured objectively. The probability and intensity of risk can be determined with high accuracy. On the under hand, uncertainty is a subjective factor. It cannot be measured and its probability and intensity cannot be predicted. Presence of a risk does not necessarily entail presence of danger. For an event to be characterized as hazardous, it has to have the potential to create conditions which lead to damage or destruction of property which is exposed to that hazard. In today's world, hazard realization can be caused by natural, industrial or biological agents (COVID-19). The causes of possible realization of risk and the hazard itself need to be given careful consideration so that a proactive approach could be taken. Apart from hazard and vulnerability, exposure is another precondition of risk. Exposure implies a number of people and/or other elements which are exposed to risk resulting from a certain event (Rejda, 2005).

The probability of damage is defined as the probability of occurrence of a harmful event and it can be presented both objectively and subjectively. The probability of damage creates a need for insurance. If this probability did not exist, there would be no need for insurance (Ćosić et al., 2011; Popović et al., 2012). The objective assessment of probability is based on the frequency of an event, whereas the subjective estimation is based on individual perception. The consequence of a harmful event is material or nonmaterial damage whose effects can be serious and capable of endangering the business activities of an employer in the long or in the short term.

For a risk to be accepted as risk in the field of insurance, it has to meet certain criteria. First and foremost, the risk that we want to insure has to be a future risk. It is irrational to insure past risks or harmful events which had minor or major consequences. The next precondition is that the risk has to be accidental, independent of the will of the insured. Otherwise, the insurer has no interest in concluding the insurance contract. Both the insurer and the insured want the harmful event not to happen. The insured party pays a smaller amount of money for their safety and the insurers cover their expenses and create certain reserves which will help them if the harmful event occurs. It is worth saying that it is impossible to insure every risk. What kind of risk can be insured is clearly defined by law.

The economic benefit of insurance is huge. It considerably increases the economic stability of individuals, companies and whole societies. Throughout history, the ways of defining the subject of insurance have changed, but the basis has remained the same - the presence of risk and the need to protect somebody or something from future uncertainties. The concept of insurance has still not taken off in less developed societies (Cosic, Popov, Novakovic et al., 2019). In developed societies, though, where buying power is stronger, the insurance sector can grow and develop. Insurance companies also become initiators of many other activities in a society because proper management of insurance funds creates conditions for appropriate investment of the money collected on insurance policy premiums.

Basic economic principles of successful business conduct are based on productivity, cost-effectiveness and profitability. Productivity can simply be defined as a desire to achieve the best possible results in insurance with the lowest cost of workforce. 
The development of modern information technologies contributes greatly to the increase in productivity of insurance companies. Cost-effectiveness deals with the relationship between the achieved result and the costs that were paid to achieve that result. Finally, profitability is an indicator that defines the amount of the invested money and the profit which was achieved in comparison with the invested amount of money. Profitability is the most significant indicator in insurance because it shows how efficiently an insurance company uses the collected money. Profitability wins the trust of potential customers and the created profit is the capital to be invested in long-term projects which result in further increase and accumulation of profit.

\section{Occupational safety and health}

The intensive development of technology in today's world creates conditions for greater safety at work. Occupational safety and health is concerned with fostering a safe and healthy work environment, relying on clearly defined measures and activities to protect the lives and health of employees. The common interest of all subjects, both individuals and the society, is to achieve the maximum degree of protection at work, minimize occupational diseases and injuries, and create conditions in which employees feel safe and satisfied while working (Živković, Taradi \& Todorović, 2013). Better working conditions are created through planned activities. These activities should focus on the creation of safe work environment and education of employees. When creating a safe workplace, both the place and the technological solutions that are used in a certain work process need to be considered. One of the best ways of preventing and controlling injuries at work is the Prevention through Design (PtD). The PtD concept involves designing the work space, its structure, tools, machines, equipment and systems of work (Todorović, Haznadarević \& Knežević, 2016). Apart from workspace, it is important to apply appropriate technical and technological solutions which will enable modern production of goods or services. The equipment and the work process should be designed in such a way that the worker is always in a safe place, at the safe distance from the equipment. Work automation and the use of modern technology prevent direct contact of employees with danger. The result is a smaller number of injuries and their reduced severity. Apart from well-designed workspace, it is necessary to develop a good organizational and safety culture. The number of injuries is not decreasing although ever more employers are using modern technological solutions. Good organizational and safety culture could certainly improve safety and health at work. Organizational culture is the result of learning and interacting internally and externally (Ivanova \& Živković, 2013).

According to The Law on Retirement and Disability Insurance of the Republic of Serbia, a workplace injury is an injury inflicted on the insured party, relating in space, time and causality to performing his/her work, based on which he/she is insured, caused by an immediate and momentary mechanical, physical or chemical impact/exposure, a sudden change in body position, a sudden and unexpected exertion of the body, or other changes in the physiological condition of the body. A workplace injury is also an injury inflicted on the insured party in the course of commuting, business trips, or travels undertaken for purposes of starting employment, as well as in other circumstances provided for in 
this Law. Health risks at work remain a constant priority of Europe because new risks occur all the time. In $2013,7.9 \%$ of the working population in the EU reported a health problem in connection to work in the previous year (Eurostat, 2017).

A workplace injury results from the combination of four main factors: potential danger, activating factors, activated danger and finally, injury. Any activity that is done in the workplace can be exposed to potential danger (slipping, stumbling, or coming into contact with an electrical voltage). The awareness of these dangers and potential injuries (near-miss) is part of prevention. What determines whether potential danger will become real danger is the activating factors. Activating factors are those activities which are not in accordance with safety measures or instructions on the use of equipment. Only when these factors are activated, a possibility of an injury is created. Does this mean that workplace injuries can be completely avoided? Many organizations boast about "'zero injuries", trying to show their concern for the employees. Still, injuries happen and will continue to happen despite all the protective measures. The real question is whether employers and the country are aware of the costs of work injuries and how these costs affect the business competence of organizations and the quality of life of the employees. Direct consequences of workplace injuries are visible and well known. The problem arises with indirect consequences which are hardly visible and not well known.

The concept of occupational safety has existed for a long time. People have always taken precautions to avoid injuries at work. With the development of technology workers are largely removed from dangerous places. This creates conditions for fewer injuries at work. In the distant past workers had very few rights concerning their safety. Workforce was abundant and the state did not interfere between employers and workers. Employers often took advantage of that situation. With the development of civilization, things have started to change. Countries start passing acts concerning the safety of workers. Employers begin to change their attitude to workers and see the workforce as s significant resource that can enable gaining comparative advantage in the marketplace. Productivity becomes highly valued. Regardless of the development of technology, the worker is the one who is in the centre of the work process and who can considerably affect productivity and, by implication, profitability.

Serious employers are becoming increasingly aware of this fact and they are ready to further invest in the competencies of the workforce because such behaviour increases the competencies of the employers themselves.

\section{Economic implications of insurance and occupational safety for business organizations}

Risk realization inevitably leads to disturbances and upheavals which can have far-reaching consequences for the economy and the whole society. It is evident that the economic function of insurance (the insured being bound to pay the premium in advance) creates favourable conditions for setting up funds which can be used at any moment to compensate the insured party. If insurance is seen as an economic category, it is clear that its main purpose is to successfully protect the owner of a property in case of danger, i.e., in case of realization of the insured risk. Insurance companies are of benefit to the modern society and the list of things that can be insured keeps growing. The percentage 
of insurance in developed countries is higher than in the developing countries because there is a significant correlation between insurance and the degree of development of a society.

In today's world of open markets, both locally and globally, it is not easy to gain the comparative advantage in selling products and services. For this reason, employers engage in the analysis of expenses, their structure and ways of controlling them and cutting down on them. They realize that costs are considerable in the case of work-related injury leave. According to the International Labour Organization, every 15 seconds a worker dies in an accident at work or as a consequence of a professional disease. Every 15 seconds 153 workers have an accident at work. Every day 6,300 people die as a consequence of workplace injury or professional disease. The number of fatalities every year amounts to 2.3 million (ILO, 2014). Careful analysis of costs shows that apart from the cost of salary for the worker who is on leave (which is $100 \%$ salary), there are other considerable costs which are not easily noticed. The economic effect of workplace injury is calculated using the cost of medical treatment, worker's compensation, damaged property, lost income, administrative expenses, etc. (Živković, Petrović \& Marković, 2015).

Investing in occupational safety creates better working conditions which further affect the quality and quantity of work. The final result is fewer and less serious injuries, reduction of negative effects connected with workplace injuries, increase in productivity and improvement of business competencies of organizations. However, today's employers need to be convinced to invest in safety at work. To justify investment in occupational safety, it is necessary to have numerous data on lost workdays, cost of gross salary of the injured, cost of damage to equipment which happened during injury, penalties for late delivery, fines, court decisions on injury compensation and an increased amount of the insurance of workers against workplace injury.

The need to observe this issue in a new way has produced a new scientific discipline of engineering economics. New methods are being used to analyze the effect of the number and severity of workplace injuries on the economic principles of productivity, efficiency and profitability. Workplace injuries may lead to huge losses such as loss of income, reduced production, costs of replacing or fixing the damaged equipment, loss of profit etc. Thus, the problem of occupational safety should be considered from the economic perspective, too. A large number of employers still think that the purchase of personal protective equipment is an expense and not an investment. As long as this opinion prevails, there will hardly be a drop in the number and severity of workplace injuries. Therefore, it is necessary to pass laws which will govern this domain and gradually change the beliefs of employers.

Employer's Liability Insurance is a large step in increasing the employers' awareness of the total costs that result from workplace injuries. Employer's Liability Insurance was introduced in Germany in 1883 in order to protect employees from consequences of workplace injuries and professional diseases. There are different solutions in the EU countries, but the bottom line is that the employer bears the cost of insurance if an injury happens at the workplace and if the injury is directly related to the activities at work. In Austria there is the Austrian Worker's Compensation Board (AUVA), professional economic societies (HVNG) in Germany, and the National Institute for Insurance against Accidents at Work (INAIL) in Italy (Spasić, 2003). Countries waiting to join the European Union will have to adjust their legislation to the legislation of the EU. 
Workplace injury is a serious risk which, if realized, could endanger the business activities of employers to a greater or lesser degree. Unfortunately, employers are often unaware of the severity of economic consequences arising from workers' injuries. Not only employers, but even states are unaware of the need for managing injury risks. Many countries still have not legally regulated this field by failing to pass the Employer's Liability Insurance Act. The Republic of Serbia is willing to pass such an act, but a lot still needs to be done. Unfortunately, safety culture in Serbia can be described as deficient, which means that legal pressure has to be put on employers and employees in order to create a safe work environment. Analyzing the laws in the neighbouring countries, it can be concluded that there are basically two types of insurance against workplace injuries. With the first type, the starting point is the so-called group methods where the price of insurance is defined through "tables" defined in advance. All jobs are grouped according to risk and accordingly have the same coefficients. This way the amount of money to be paid per an insured person is easily determined. The problem with this method is that it unjustly unifies all organizations from the same group, both those which place a high value on safety and those which do not. The Republic of Croatia is a typical example of this, where a defined percentage of money goes to a specially designed fund for injury compensation simultaneously with paying salaries to employees. The problem with this method is the fact that the percentage is the same for both those employers where no workplace injuries happen and for those where they do happen. Why, then, would the employers care about occupational safety at all?

The alternative to this method is the model of individual charging where every employer is analyzed separately and charged upon the results (lost workdays, number of injuries, etc.). The shortcoming of this method is that insurance company agents are required to have basic knowledge of safety at work so that they could adequately estimate risks, both for the insurer and for the insured. In the developed world, whose part we are striving to become, workplace insurance is an important issue in the business plan of every organization. Insurance agents, analyzing workplace safety in individual companies, define the amount of insurance to be paid for every employee for the coming period. It is in the interest of employers, therefore, to minimize the number of injuries and lost workdays in the defined period.

\section{Conclusion}

In the final analysis, insurance is an instrument that enables active risk management. Grouping employers exposed to similar risks enables protection from the uncertainty of risk over a certain period. This way of looking at insurance increases the business potential of organizations and the whole society. On the other hand, an increasing number of employers are becoming aware of the cost of workplace injuries and are trying to prepare for the potential risk of workplace injuries. Insurance is a helpful instrument in managing the risk of workplace injuries. Employers buy work injury compensation insurance to protect their own interests and to provide better conditions for the recovery of workers in case of injury. In conclusion, the paper has confirmed the hypothesis about the connection between insurance and workplace injuries and that insurance against these injuries contributes to a better and more certain future of employers, employees and the society as a whole. 


\section{References}

Andrijanić, I., \& Klasić, K. (2002). Tehnika osiguranja i reosiguranja. Zagreb: Mikrorad.

Avdalović, S., Ćosić, Đ., \& Avdalović, V. (2010). Osnove osiguranja sa upravljanjem rizikom. Novi Sad: Fakultet tehničkih nauka.

Cosic, D., Popov, S., Novakovic, T., \& Popovic, Lj. (2019). Flood damage assessment method: GIS based approach. Fresenius Environmental Bulletin, 28(3), 18961904.

Ćosić, Đ., Popov, S., Sakulski, D., \& Frank, A. (2011). Geo-information technology for disaster risk assessment. Acta Geotechnica Slovenica, 8(1), 65-74.

Ćosić, Đ., Popović, Lj., Novaković, T., Rizaj, A., \& Silo, E. (2019). Microfinance products as tool for financial resilience to hazards, In 2. K-FORCE: Knowledge for resilient society Conference (pp. 59-64), Tirana; Epoka University, Faculty of Architecture and Engineering.

Eurostat. (2017). Self-reported work-related health problems and risk factors key statistics. Luxembourg: Author. Retrieved March 29, 2020, from: https:// ec.europa.eu/eurostat/statistics-explained/index.php/Self-reported_workrelated_health_problems_and_risk_factors_-_key_statistics

Илић Петковић, А. (2016). Правни аспекти безбедности и здравља на раду у Србији. In Ж. Ћулибрк (Ed.), Савремени безбједносни ризици и пријетње и ґихов утииај на безбједност држава региона (рp. 315-324). Бањалука: Факултет за безбједност и заштиту.

Ilić Petković, A., Vukić, T., Furtula, M. \& Nikolić, V. (2019). Knowledge of legal regulations as conditio sine qua non in safety management. In J. Taradi (Ed.), 14. Conference Management and Safety - M\&S2019 (pp. 51-58). Budva: The European Society of Safety Engineers.

International Labour Organization. (2014). Safety and health at work: A vision for sustainable prevention, In XX World Congres on Safety and Health at Work, Global Forum for Prevention, Frankfurt: German Social Accident Insurance / International Social Security Association.

Ivanova, T., \& Živković, S. (2013). Improving a company's competitiveness - a case study. In Improving the competitiveness of enterprises and national economies - determinants and solutions, Thematic collection of papers of international significance (pp. 231-248). Niš: Faculty of Economics in Niš.

Mrkšić, D., \& Ćosić, Đ. (2015). Upravljanje rizikom i osiguranje. Novi Sad: Fakultet tehničkih nauka / FTN Grafički centar GRID.

Njegomir, V., \& Ćosić Đ. (2012). Ekonomske implikacije klimatskih promena na sektor osiguranja i reosiguranja. Teme, 36(2), 679-701.

Novaković, T., Bondžić, J., Ćosić, Đ., \& Miškić, M. (2017). Flood risk damage assessment, In 17. International Scientific Conference on Industrial Systems - IS17 (pp. 410-413). Novi Sad: University of Novi Sad, Faculty of Technical Sciences. 
Novaković, T., Jevtić, M., Bondžić, J., Popović, Lj., Ćosić, Đ., Popov, S., Laban, M., $\&$ Radonjanin, V. (2018). Insurance and disaster risk management: Reduction vulnerability and risk, In 1. S-FORCE: Knowledge for Resilient Society Conference (pp. 79-86). Novi Sad: University of Novi Sad, Faculty of Technical Sciences.

Popović, Lj., Novaković, T., Bondžić, J., Ćosić, Đ., \& Popov, S. (2012). Impact of prevention measures on fire insurance premium, In 13. Međunarodna konferencija zaštita od požara i eksplozija (pp. 43-52). Novi Sad: Visoka tehnička škola strukovnih studija.

Rejda, G. E. (2005). Principles of risk management and insurance (9th ed.). Boston: Addison-Wesley.

Spasić, D. (2003). Ekonomika zaštite na radu. Niš: Grafika Galeb.

Todorović, M., \& Živković, S. (2010). Organizational culture in the function of occupational health care at work, In 13. International conference - Life Cycle Engineering and Management ICDQM - 2010 (pp. 155-161). Belgrade: DQM Research Center.

Todorović, M., Haznadarević, L., \& Knežević, D. (2016). Održivi razvoj u funkciji poboljšanja uslova za bezbedan rad, In XI. Međunarodna konferencija Menadžment $i$ sigurnost -M\&S 2016 (pp. 231-243). Vrnjačka banja: The European Society of Safety Engineers.

Vujović, R. (2009). Upravljanje rizicima i osiguranjem. Beograd: Univerzitet Singidunum.

Živković, S., Petrović, D., \& Marković, Z. (2015). Analiza uticaja ljudskog faktora kod povreda na radu, In 18. Međunarodna konferencija Upravljanje kvalitetom i pouzdanošću ICDQM-2015 (pp. 339-345). Prijevor: Istraživački centar DQM.

Živković, S., Taradi, J., \& Todorović, M. (2013). Comparative analysis of research on work-related problems of occupational safety specialist in Croatia and Serbia. Technics Technologies Education Management, 8(4), 1840-1848. 